\title{
Peningkatan Motivasi Mengajar dan Keterampilan Menggunakan TIK Dalam Pembelajaran Daring di Masa Pandemi Covid-19
}

\author{
Suhartono \\ SMP Negeri I Gegesik Kabupaten Cirebon \\ e-mail: hrsuhartono6502@gmail.com
}

\begin{abstract}
The problem that will be solved in this School Action Research is whether the implementation of FGDs conducted by school principals can increase motivation and skills in using ICT in implementing online learning during the Covid 19 pandemic for teachers of SMP Negeri I Gegesik, Cirebon Regency? The purpose of this study was to find out whether through the implementation of programmed FGDs by researchers could increase the motivation and skills of using ICT for teachers in implementing online learning. The research subjects were teachers of SMP Negeri I Gegesike Cirebon Regency. The research period was six months, starting from July to December 2020. Each cycle consists of 4 activity stages, namely planning, implementing actions, observing and reflecting. The results showed that the average motivation and skills of teachers using ICT in online learning had increased significantly in each cycle. This can be seen from the average value in the initial conditions before the action was carried out, the average value of the first cycle and the second cycle. In the initial conditions, the average value of motivation is $2.48(C+)$, in the first cycle the average increases to $2.74(B$-) and in the second cycle it increases again to $3.26(B+)$. While the increase in the skills of teachers using ICT in online learning also increased, namely in the pre-cycle the average teacher performance was $2.48(C+)$, in the first cycle the average increased to 2.71 (B-), and in the second cycle it increased again. becomes 3.13 (B). By looking at this increase in value, it can be concluded that it turns out that the implementation of FGDs conducted by researchers can increase motivation and skills in using ICT for teachers in online learning during the Covid 19 pandemic.
\end{abstract}

Keywords: motivation; ICT skills, online learning, FGD

\begin{abstract}
ABSTRAK
Permasalahan yang akan dipecahkan dalam Penelitian Tindakan Sekolah ini adalah apakah pelaksanaan FGD yang dilakukan oleh kepala sekolah dapat meningkatkan motivasi dan keterampilanmenggunakan TIK dalam pelaksanaan pembelajaran daring masa pandemi covid 19 bagi guru SMP Negeri I Gegesik Kabupaten Cirebon? Tujuan penelitian ini adalah ingin mengetahui apakah melalui pelaksanaan FGD yang dilakukan secara terprogram oleh peneliti dapat meningkatkan motivasi dan keetrampilan menggunakan TIK bagi guru dalam melaksanakan pembelajaran daring. Subjek penelitian adalah guru SMP Negeri I Gegesik Kabupaten Cirebon. Waktu penelitian adalah selama enam bulan, dimulai pada bulan Julisampai dengan bulan Desember 2020. Setiap siklus terdiri dari 4 tahap kegiatan yaitu perencanaan, pelaksanaan tindakan, observasi dan refleksi. Hasil penelitian menunjukkan bahwa rata-rata motivasi dan keterampilan guru menggunakan TIK dalam pembelajaran daring mengalami peningkatan secara signifikan pada setiap siklusnya. Hal ini dapat dilihat dari rata-rata nilai pada kondisi awal sebelum dilaksanakan tindakan, rata-rata nilai siklus I dan siklus II. Pada kondisi awal nilai rata-rata motivasi adalah 2,48 (C+), pada siklus I rata-rata meningkat menjadi 2,74 (B-) dan pada siklus II meningkat lagi menjadi 3,26 $(\mathrm{B}+)$. Sedangkan peningkatan keterampilan guru menggunakan TIK dalam pembelajaran daringjuga terjadi peningkatan, yaitu pada prasiklus rata-rata kinerja guru sebesar 2,48 $(\mathrm{C}+)$, pada siklus I rata-ratanya meningkat menjadi 2,71 (B-), dan pada siklus II meningkat lagi menjadi 3,13 (B). Dengan melihat peningkatan nilai tersebut maka dapat disimpulkan bahwa ternyata pelaksanaan FGD yang dilakukan oleh penelitidapat meningkatkan motivasi dan keterampilanmenggunakan TIK bagi guru dalam pembelajaran daring pada masa pandemi covid 19.
\end{abstract}

Kata Kunci: motivasi; keterampilan TIK, pembelajaran daring, FGD

Submitted Apr 17, 2021 | Revised May 03, 2021 | Accepted May 06, 2021

\section{Pendahuluan}

Kepala sekolah memegang peranan penting dalam perkembangan sekolah. Oleh karena itu, ia harus memiliki jiwa kepemimpinan untuk mengatur para guru pegawai tata usaha dan pegawai sekolah lainnya (Ridho, 2019; Maimunah, et al., 2019; Khairuddin, 2020). Tetapi belum semua kepala sekolah 
mengerti maksud kepemimpinan, kualitas serta fungsi-fungsi yang harus dijalankan oleh pemimpin pendidikan. Dalam hal ini, kepala sekolah tidak hanya mengatur para guru saja, melainkan juga ketatausahaan sekolah siswa, hubungan sekolah dengan masyarakat dan orang tua siswa (Marzuki \& Irawati, 2018; Muslih, 2020). Tercapainya tujuan sekolah sepenuhnya bergantung pada bijaksana yang terapkan kepala sekolah terhadap seluruh personal sekolah (Wahed, 2016).

Namun pada kenyataannya masih banyak kepala sekolah/madrasah yang belum mampu untuk memimpin dan mengelola sekolah/madrasah. Sehingga upaya meningkatkan mutu pendidikan,masih jauh dari harapan. Dalam melaksanakan fungsinya sebagai pimpinan administrator pendidikan di sekolah, kepala sekolah harus bertanggung jawab terhadap kelancaran pelaksanaan pendidikan dan pengajaran di sekolahnya (Jasman, 2017; Astuti, 2019; Muflihah \& Haqiqi, 2019). Fakta menunjukkan bahwa kepala sekolah belum maksimal dalam melaksanakan fungsinya sebagai pimpinan administrator pendidikan di sekolah. Hal ini sejalan dengan Permendiknas Nomor: NOMOR 28 TAHUN 2010 ,Kepala sekolah/madrasah adalah guru yang diberi tugas tambahan untuk memimpin taman kanakkanak/raudhotul athfal (TK/RA), taman kanak-kanak luar biasa (TKLB), sekolah dasar/madrasah ibtidaiyah (SD/MI), sekolah dasar luar biasa (SDLB), sekolah menengah pertama/madrasah tsanawiyah (SMP/MTs), sekolah menengah pertama luar biasa (SMPLB), sekolah menengah atas/madrasah aliyah (SMA/MA), sekolah menengah kejuruan/madrasah aliyah kejuruan (SMK/MAK), atau sekolah menengah atas luar biasa (SMALB) yang bukan sekolah bertaraf internasional (SBI) atau yang tidak dikembangkan menjadi sekolah bertaraf internasional (SBI)..

Di masa pandemi covid-19 Kepala sekolah diharapkan semakin aktif dalam melakukan tugas kepada guru untuk memberikan jaminan bahwa pelaksanaan pembelajaran daring pada masa pandemi tetap dapat berjalan secara efektif dan efisien melalui berbagai aplikasi pembelajaran daring untuk supporting kesuksesan pembelajaran daring yang dilakukan. Pembelajaran dari rumah yang telah ditetapkan oleh pemerintah pada masa pandemi covid-19 harus disikapi dengan bijaksana oleh seluruh civitas akademika, termasuk pengawas madrasah. Pengawas madrasah harus selalu mendorong guru agar mengoptimalkan segenap kemampuannya untuk dapat menyelenggarakan pembelajaran dari rumah ecara efektif dan efisien, sehingga dimasa pandemi covid-19 ini, siswa tetap mendapatkan pelayanan pendidikan dan pembelajaran.

Semenjak tanggal 11 Maret 2020 WHO (World Health Organization) atau badan kesehatan dunia telah mengumumkan status pandemi global untuk Corona Virus Disease 2019 atau Covid-19 penyakit ini telah mewabah secara global dan menyerang banyak korban di berbagai negara (Nahdi \& Jatisunda, 2020). Akibat wabah tersebut, maka seluruh warga dunia dapat berpotensi terinfeksi covid-19. Oleh karena itu sudah sangat tepat jika akhirnya pemerintah mengambil kebijakan agar anak belajar di rumah. Kepala sekolah selaku komponen penjaminan mutu harus mampu melakukan tindakantindakan untuk mendorong guru agar tetap mampu mengembangkan berbagai inovasi dan kreativitas pembelajaran (Puspitasari, 2018), di masa pandemi covid-19 ini. Kepala sekolah perlu memberikan sebuah treatment agar motivasi guru dan penguasaan guru terhadap Teknologi Informasi dan Komunikasi (TIK) meningkat, sehingga tetap dapat menyelenggarakan pendidikan dan pembelajaran daring dengan baik. Sejalan dengan kebijakan pemerintah dengan penerapan pembelajaran dari rumah, maka pembelajaran daring (dalam jaringan) dengan pemanfaatan TIK dapat dijadikan sebagai salah satu solusi untuk melakukan pembelajaran dimasa pandemi ini. Oleh karena itu, dalam pelaksanaan pembelajaran daring antara siswa dan guru harus sama-sama aktif dan sama-sama menguasai TIK agar pembelajaran daring dapat dilaksanakan dengan baik dan lancer (Anugrahana, 2020).

Memandang kondisi ini, kepala sekolah harus melakukan tindakan-tindakan dalam menjalankan tugas dan fungsinya untuk memberikan solusi guna membantu guru dan siswa mengatasi permasalahan pembelajaran daring, terutama dalam meningkatkan motivasi mengajar, penguasaan TIK dan bagaimana cara mengoptimalkan keterampilan guru dalam penggunaan TIK agar guru dan siswa dapat 
melakukan proses belajar dengan baik dan lancar. Kepala sekolah harus dapat mengambil langkah yang tepat, sehingga layanan pendidikan dan pembelajaran dimasa pandemi ini tetap dapat berjalan optimal.

Rendahnya motivasi dan keterampilan guru dalam memanfaatkan TIK akan menjadi sebuah permasalahan yang mengakibatkan rendahnya motivasi belajar yang berimplikasi pada menurunnya hasil belajar siswa. Oleh karena itu, pengawas madrasah harus berupaya untuk meningkatkan motivasi mengajar dan keterampilan guru menggunakan TIK dengan baik. Oleh karena itu peneliti yang juga sebagai pengawas madrasah melakukan tindakan untuk peningkatan motivasi dan keterampilan guru menggunakan TIK dalam pembelajaran daring yang dikaji dalam sebuah Penelitian Tindakan Sekolah (PTS).

Tindakan yang dilakukan oleh penulis, sebagai kepala sekolah SMP Negeri I Gegesik Kabupaten Cirebon, adalah membantu guru dalam pelaksanaan pembelajaran daring pada masa pandemi covid-19 adalah dengan upaya meningkatkan motivasi dan keterampilan guru memanfaatkan TIK dalam pembelajaran daring melalui FGD (Focus Group Discussion).

Focus Group Discussion saat ini populer dan sering digunakan sebagai metode untuk pengumpulan data dalam penelitian social (Kasir, 2018). Focus group discussion (FGD) atau diskusi kelompok terarah adalah pertemuan yang sifatnya terarah untuk membahas topik yang fokus (dipersempit) yang difasilitasi oleh peneliti dengan panduan pertanyaan dalam proses kelompok sehingga tidak terjebak dengan wawancara individual. FGD yang dilakukan dimaksudkan agar dapat membantu guru secara efektif, mengetahui permasalahan yang dihadapi oleh masing-masing guru dengan pendekatan kolegial. Beberapa hasil penelitian terdahulu juga membuktikan bahwa FGD dapat meningkatkan kemampuan dan kinerja guru. Penelitian tersebut diantaranya Siregar (2018) berhasil meningkatkan kemampuan guru dalam menerapkan pembelajaran kontekstual, Hutagalung (2018) berhasil meningkatkan kinerja guru, dan Nuruningsih \& Palupi (2021) juga berhasil meningkaaatkan kompetensi guru dalam penyusunan Rencana Pelaksanaan Pembelajaran (RPP).

Berdasarkan pemaparan latar belakang penelitian di atas, penelitian ini bertujuan untuk meningkatkan motivasi dan keterampilan menggunakan TIK dalam pembelajaran daring masa pandemi Covid-19 melalui FGD bagi guru SMP Negeri I Gegesik Kabupaten Cirebon Pada Semester 1 Tahun Pelajaran 2020/2021. Dengan melakukan FGD peneliti berharap guru dapat bersikap terbuka mengemukakan permasalahan yang dihadapi kemudian peneliti mengambil sebuah tindakan yang secara umum dapat diterima oleh guru, dimana target FGD yang dilakukan adalah peningkatan motivasi dan keterampilan guru dalam pemanfaatan TIK bagi guru SMP Negeri I Sumber Kabupaten Cirebon Tahun pelajaran 2020 /2021. Dengan peningkatan motivasi mengajar dan penguasaan keterampilan menggunakan TIK, diharapkan guru dapat mengembangkan dan melaksanakan pembelajaran daring dengan baik.

\section{Metode Penelitian}

Jenis penelitian ini adalah Penelitian Tindakan Sekolah, atau yang biasa disebut PTS. Dengan demikian, penelitian ini sifatnya berbasis sekolah. Penelitian tindakan sekolah ini juga diharapkan dapat meningkatkan kualitas pendidikan dan pembelajaran yang nantinya dapat berimplikasi pada peningkatan prestasi sekolah

Aspek yang diteliti dalam Penelitian Tindakan Sekolsh (PTS) ini adalah motivasi dan keterampilan guru dalam melaksanakan pembelajaran daring melalui FGD yang dilakukan oleh pengawas madrasah dalam hal ini juga sebagai peneliti. Rencana Penelitian Tindakan Sekolah (PTS) dilaksanakan dalam dua siklus, dan tiap siklus terdiri dari empat tahap yaitu ; tahap perencanaan tindakan (planning), tahap pelaksaaan tindakan (acting), tahap observasi dan evaluasi (observasing and evaluating) dan tahap refleksi (reflecting). Sebagaimana dikemukakan oleh Taggard (1981) dalam penelitian ini disajikan dalam gambar 1. 


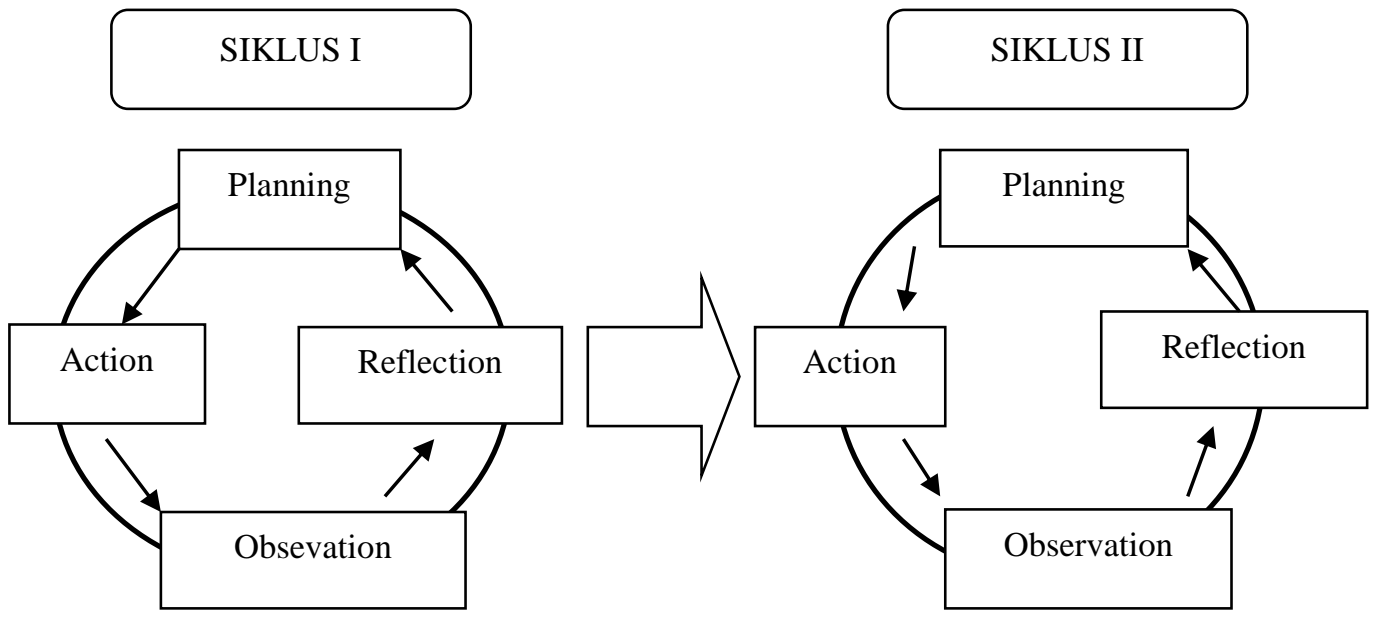

Gambar 1. Desain Penelitian Tindakan Sekolah

Dalam penelitian ini dilakukan FGD sebagai tindakan untuk meningkatkan motivasi dan keterampilan guru dalam pembelajaran daring di masa pandemi covid-19 bagi guru SMP Negeri I Gegesik Kabupaten Cirebon pada semester I tahun pelajaran 2020/2021. Subjek penelitian ini adalah guru SMP Negeri I Gegesik Kabupaten Cirebon semester I tahun pelajaran 2020/2021 sebanyak 49 guru.

Penelitian ini dilakukan di SMP Negeri I Gegesik Kabupaten Cirebon. Dengan penelitian ini diharapkan dapat berimplikasi pada peningkatan pelayanan pendidikan dan pembelajaran pada sekolah tempat dimana peneliti bertugas. Waktu penelitian dilaksanakan selama 6 (enam) bulan yaitu dimulai pada bulan Juli 2020 dan berakhir pada bulan Desember tahun 2020 pada semester I tahun pelajaran 2020/2021. Siklus I dilaksanakan pada bulan Juli-September 2020 dan siklus II dilaksanakan pada bulan Oktober-Desember 2020.

Instrumen penelitian yang digunakan untuk pengumpulan data dalam penelitian ini berupa instrumen penilaian motivasi dan keterampilan guru menggunakan TIK dan nontes. Instrumen penilaian motivasi dan keterampilan guru menggunakan TIK digunakan untuk mengetahui tingkat motivasi dan keterampilan guru dalam mengoperasionalkan perangkat lunak dalam pembelajaran daring masa pandemi covid-19. Adapun instrumen nontes digunakan untuk mengetahui aktifitas guru sebagai subjek penelitian selama proses penelitian berlangsung.

Analisis data yang digunakan dalam penelitian ini adalah analisis data deskriptif kualitatif, yaitu suatu metode penelitian yang bersifat menggambarkan kenyataan atau fakta sesuai dengan data yang diperoleh dengan tujuan untuk mengetahui tingkat motivasi dan keterampilan guru menggunakan TIK dalam pelaksanaan pembelajaran daring di masa pandemi covid-19. Analisis deskriptif kualitatif dalam penelitian ini menggunakan statistik sederhana yang dipergunakan untuk menghitung nilai peningkatan motivasi dan keterampilan guru menggunakan TIK dalam pelaksanaan pembelajaran daring di masa pandemi covid-19. Penilaian motivasi dan keetrampilan guru menggunakan TIK ditulis dalam skala 100 kemudian dikonversi menjadi skala 4. Adapun teknik konversi pada analisis data dalam penelitian ini dihitung dengan menggunakan statistik sederhana

\section{Hasil dan Pembahasan}

Berdasarkan deskripsi pelaksanaan FGD yang dilakukan oleh peneliti dari prasiklus, siklus I, sampai dengan siklus II, didapatkan peningkatan motivasi dan keterampilan guru menggunakan TIK secara signifikan. Peningkatan ini dapat dilihat dari data-data penilaian motivasi, keterampilan guru menggunakan TIK, aktivitas peneliti dan aktivitas guru sebagai subjek penelitian selama proses tindakan berlangsung. 
Secara rinci data peningkatan motivasi, keterampilan guru menggunakan TIK, aktivitas peneliti, dan aktivitas guru sebagai subjek penelitian dapat dilihat pada pembahasan hasil penelitian sebagai berikut.

1. Peningkatan Motivasi Guru

Berdasarkan analisis data yang didapat pada setiap siklus yang dilakukan oleh peneliti, maka dapat diketahui peningkatan motivasi guru setelah dilakukan FGD oleh peneliti pada setiap siklusnya. Rekapitulasi data motivasi guru dapat dilihat pada gambar 1.

Tabel 1. Hasil Rata-Rata Penilaian Motivasi Guru SMP Negeri I Gegesik

\begin{tabular}{|c|c|c|c|c|}
\hline \multirow{2}{*}{ No } & \multirow{2}{*}{ Nama Guru } & \multicolumn{3}{|c|}{ Siklus } \\
\hline & & Prasiklus & I & II \\
\hline 1 & H. Yusup, S.Ag. & 2,51 & 2,71 & 3,23 \\
\hline 2 & Hj. Casmi, S.Pd. & 2,55 & 2,80 & 3,31 \\
\hline 3 & Enung Purkonah, S.Pd. & 2,44 & 2,78 & 3,23 \\
\hline 4 & H. Yan Yan Suwandi, S.Pd. & 2,45 & 2,71 & 3,22 \\
\hline 5 & H. Ikhya, S.Pd. Ekop. & 2,50 & 2,76 & 3,28 \\
\hline 6 & Sukasa, S.Pd.Bio & 2,54 & 2,79 & 3,32 \\
\hline 7 & Hj. Samiah, S.Pd. & 2,45 & 2,73 & 3,27 \\
\hline 8 & Koriah, S.Pd. & 2,44 & 2,69 & 3,25 \\
\hline 9 & H. Mahadi,S.Pd. & 2,45 & 2,65 & 3,23 \\
\hline 10 & H. Dadang Kurniadi, S.Pd. & 2,51 & 2,71 & 3,23 \\
\hline 11 & Hj. Masriah, S.Pd. & 2,55 & 2,80 & 3,31 \\
\hline 12 & Undang Kuswana, S.Pd. & 2,44 & 2,78 & 3,23 \\
\hline 13 & Manis Rihernati, S.Pd. & 2,45 & 2,71 & 3,22 \\
\hline 14 & Wiwin Kurniawati, S.Pd. & 2,50 & 2,76 & 3,28 \\
\hline 15 & Amin Muhaemin, S.Pd. & 2,54 & 2,79 & 3,32 \\
\hline 16 & Sukesih, S.Si. & 2,45 & 2,73 & 3,27 \\
\hline 17 & Aksodi, S.Pd. & 2,44 & 2,69 & 3,25 \\
\hline 18 & Ninis Imsiana, S.Pd. & 2,45 & 2,65 & 3,23 \\
\hline 19 & Satimah, S.Pd. & 2,51 & 2,71 & 3,23 \\
\hline 20 & Elin Parlina, S.Pd. & 2,55 & 2,80 & 3,31 \\
\hline 21 & Lien Herlina, S.S. & 2,44 & 2,78 & 3,23 \\
\hline 22 & Agtus Priyadi, SE & 2,45 & 2,71 & 3,22 \\
\hline 23 & Bakhrul Alam, S.Pd. & 2,50 & 2,76 & 3,28 \\
\hline 24 & Suilah, S.Ag. & 2,54 & 2,79 & 3,32 \\
\hline 25 & Sapi'i,S.Pd.I & 2,45 & 2,73 & 3,27 \\
\hline 26 & Asruni, S.Pd. & 2,44 & 2,69 & 3,25 \\
\hline 27 & Sri Watiah, S.Pd. & 2,45 & 2,65 & 3,23 \\
\hline 28 & Any Nuryani, S.Pd. & 2,51 & 2,71 & 3,23 \\
\hline 29 & Siti Cahyani, S.Pd. & 2,55 & 2,80 & 3,31 \\
\hline 30 & Supriyanto, S.Pd. & 2,44 & 2,78 & 3,23 \\
\hline 31 & Sa'diyah, S.Pd. & 2,45 & 2,71 & 3,22 \\
\hline 32 & Nining Widyaningsih, S.Pd. & 2,50 & 2,76 & 3,28 \\
\hline 33 & Amyati Febriani, S.Pd. & 2,54 & 2,79 & 3,32 \\
\hline 34 & Sevi Apriani, S.Pd. & 2,45 & 2,73 & 3,27 \\
\hline 35 & Nuraepih, S.Pd. & 2,44 & 2,69 & 3,25 \\
\hline 36 & Dedi Iskandar, S.Pd. & 2,45 & 2,65 & 3,23 \\
\hline 37 & Fitria Hasana'ul Fatihah, S.Pd.I & 2,51 & 2,71 & 3,23 \\
\hline 38 & Zahroh Habibati,S.Pd.I & 2,55 & 2,80 & 3,31 \\
\hline 39 & Feggy Trisnawati, S.Pd. & 2,44 & 2,78 & 3,23 \\
\hline 40 & Indah Puspitasari, S.Pd. & 2,45 & 2,71 & 3,22 \\
\hline 41 & Nurul Anwar, S.Pd.I & 2,50 & 2,76 & 3,28 \\
\hline 42 & Akhmad Rifai, S.Pd. & 2,54 & 2,79 & 3,32 \\
\hline 43 & Ruslani,S.Pd.I & 2,45 & 2,73 & 3,27 \\
\hline
\end{tabular}




\begin{tabular}{|c|c|c|c|c|}
\hline 44 & Moh. Tarsadi,S.Pd. & 2,44 & 2,69 & 3,25 \\
\hline 45 & Rizal Khamami, S.Psi & 2,45 & 2,65 & 3,23 \\
\hline 46 & Rochman F, S.Pd. & 2,51 & 2,71 & 3,23 \\
\hline 47 & Moh. Ali Z, S.Pd. & 2,55 & 2,80 & 3,31 \\
\hline 48 & Khotimah, S.Pd. & 2,44 & 2,78 & 3,23 \\
\hline 49 & Dadang Cahyanto, S.Pd. M.M.Pd. & 2,45 & 2,71 & 3,22 \\
\hline & Jumlah Nilai & 121 & 134 & 159 \\
\hline & Rata-rata & 2,48 & 2,74 & 3,26 \\
\hline
\end{tabular}

Jika data tersebut dibuat dalam bentuk diagram, maka akan tampak seperti pada gambar 2 sebagai berikut.

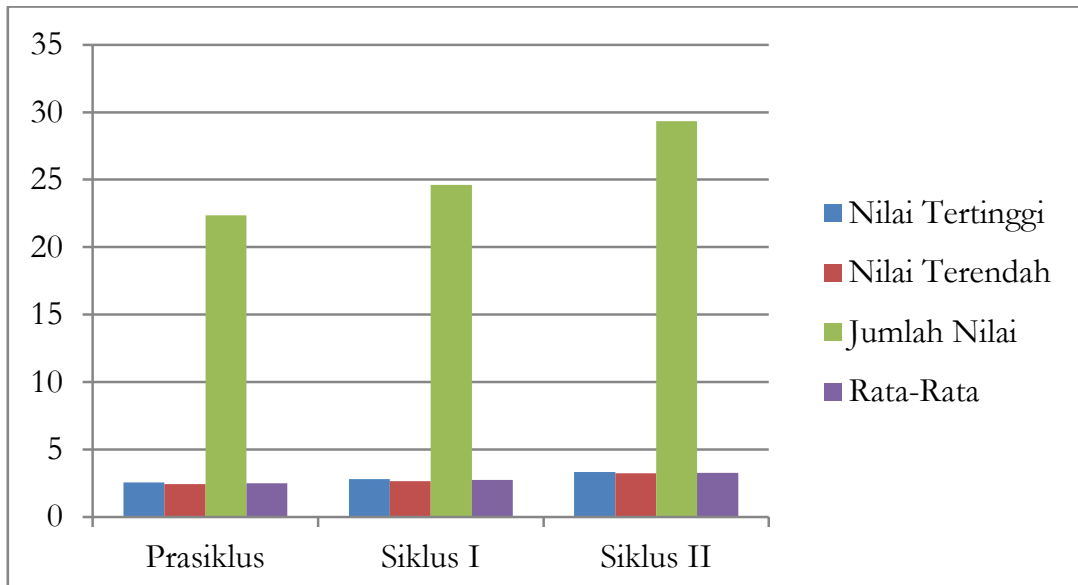

Gambar 2. Hasil Rata-Rata Penilaian Motivasi Guru Kelas SMP Negeri I Gegesik

Berdasarkan data pada tabel 1 dan gambar 2, tampak bahwa pada prasiklus rata-rata nilai motivasi guru sebesar 2,48 kategori cukup (C+), kemudian meningkat 0,26 poin menjadi 2,74 kategori baik (B-) pada siklus I, kemudian meningkat lagi sebesar 0,52 poin menjadi 3,26 kategori baik $(B+)$.

2. Peningkatan Keterampilan Guru Menggunakan TIK

Berdasarkan analisis data yang didapat pada setiap siklus yang dilakukan oleh peneliti, maka dapat diketahui peningkatan keterampilan guru menggunakan TIK setelah dilakukan FGD oleh peneliti pada setiap siklusnya. Rekapitulasi data keterampilan guru menggunakan TIK dapat dilihat pada gambar 2 .

Tabel 2. Hasil Rata-Rata Penilaian Keterampilan Guru SMP Negeri I Gegesik

\begin{tabular}{clccc}
\hline \multirow{2}{*}{ No } & \multicolumn{1}{c}{ Nama Guru } & Siklus & II \\
\hline 1 & Khotimah, S.Pd. & 2,51 & I & 2,71 \\
2 & Dadang Cahyanto, S.Pd. M.M.Pd. & 2,53 & 2,76 & 3,11 \\
3 & H. Yusup, S.Ag. & 2,44 & 2,71 & 3,16 \\
4 & Hj. Casmi, S.Pd. & 2,44 & 2,68 & 3,09 \\
5 & Enung Purkonah, S.Pd. & 2,51 & 2,75 & 3,16 \\
6 & H. Yan Yan Suwandi, S.Pd. & 2,52 & 2,80 & 3,19 \\
7 & H. Ikhya, S.Pd. Ekop. & 2,44 & 2,71 & 3,16 \\
8 & Sukasa, S.Pd.Bio & 2,44 & 2,65 & 3,11 \\
9 & Hj. Samiah, S.Pd. & 2,48 & 2,63 & 3,12 \\
10 & Koriah, S.Pd. & 2,51 & 2,71 & 3,11 \\
11 & H. Mahadi,S.Pd. & 2,53 & 2,76 & 3,16 \\
12 & H. Dadang Kurniadi, S.Pd. & 2,44 & 2,71 & 3,11 \\
13 & Hj. Masriah, S.Pd. & 2,44 & 2,68 & 3,09 \\
\hline
\end{tabular}




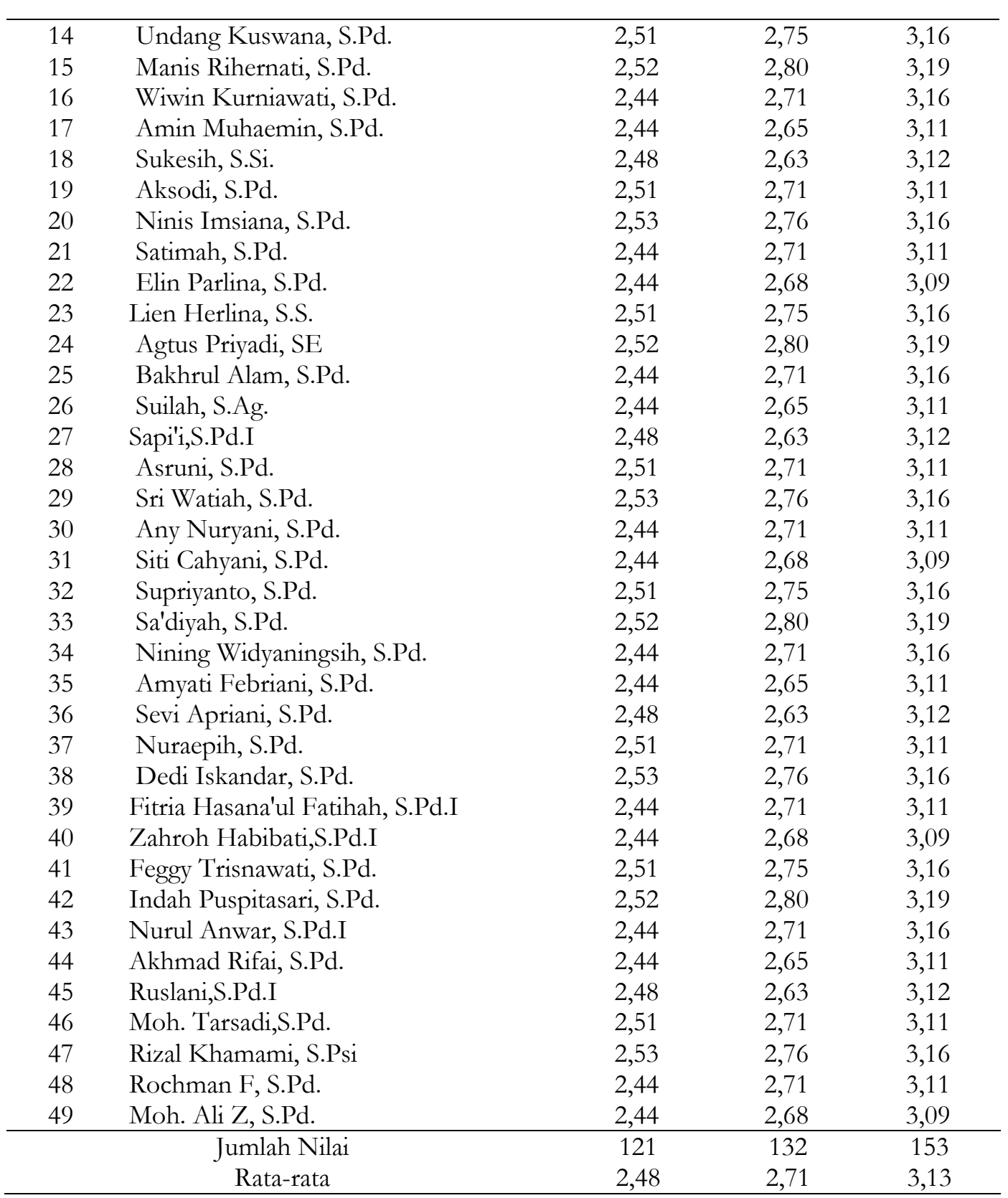

Jika data tersebut dibuat dalam bentuk diagram, maka akan tampak seperti pada gambar 3 berikut.

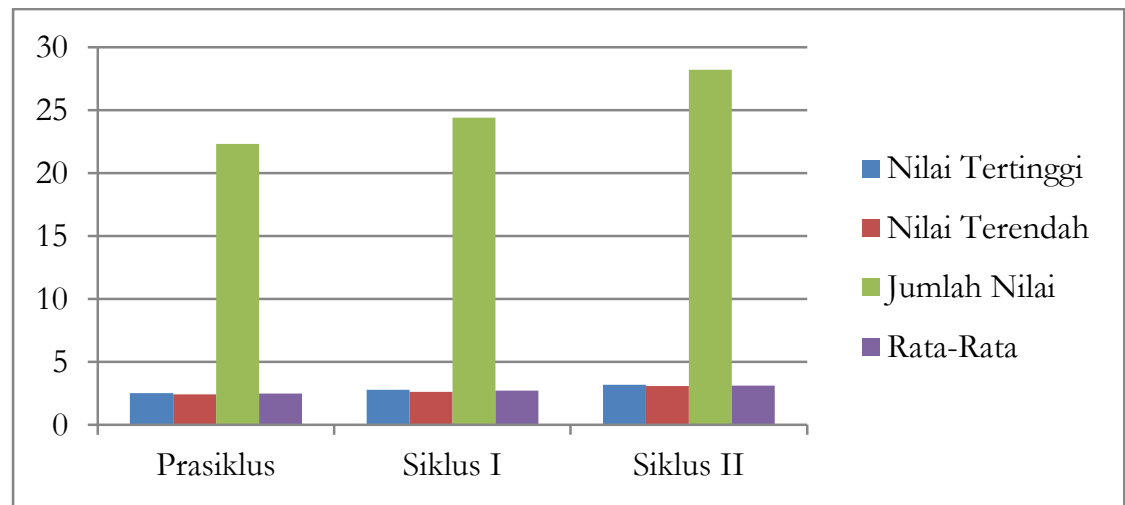

Gambar 3. Hasil Rata-Rata Penilaian Keterampilan Guru SMP Negeri I Gegesik 
Berdasarkan data pada tabel 2 dan gambar 3, tampak bahwa pada prasiklus rata-rata nilai keterampilan guru menggunkan TIK sebesar 2,48 kategori cukup (C+), kemudian meningkat 0,23 poin menjadi 2,71 kategori baik (B-) pada siklus I, kemudian meningkat lagi sebesar 0,42 poin menjadi 3,13 kategori baik (B).

3. Peningkatan Aktivitas Peneliti

Berdasarkan pengamatan yang dilakukan oleh observer, aktivitas peneliti dalam pelaksanaan FGD pada siklus I dan siklus II juga juga mengalami peningkatan kinerja. Adapun data peningkatan tersebut dapat dilihat pada tabel 3 dan gambar 4.

Tabel 3. Hasil Observasi Aktivitas Peneliti Pada Siklus I dan Siklus II

\begin{tabular}{llcc}
\hline \multirow{2}{*}{ No } & \multicolumn{1}{c}{ Indikator Keaktifan } & \multicolumn{2}{c}{ Indeks Skor 4 } \\
& \multicolumn{1}{|c}{ Siklsu I } & Siklus II \\
\hline 1. & Pengelolaan dalam pelaksanaan FGD & 3,50 & 3,80 \\
2. & Manajemen waktu & & \\
3. & Penguasaan konsep pembimbingan dan & 2,50 & 3,50 \\
& motivasi & 2,25 & 3,65 \\
4. & Penguasaan materi pengunaan TIK untuk & 2,70 & 3,25 \\
& pembelajaran daring & 2,74 & 3,55 \\
$\quad$ Rata - rata
\end{tabular}

Jika data tersebut disajikan dalam bentuk diagram, maka akan tampak seperti pada Gambar 4. sebagai berikut.

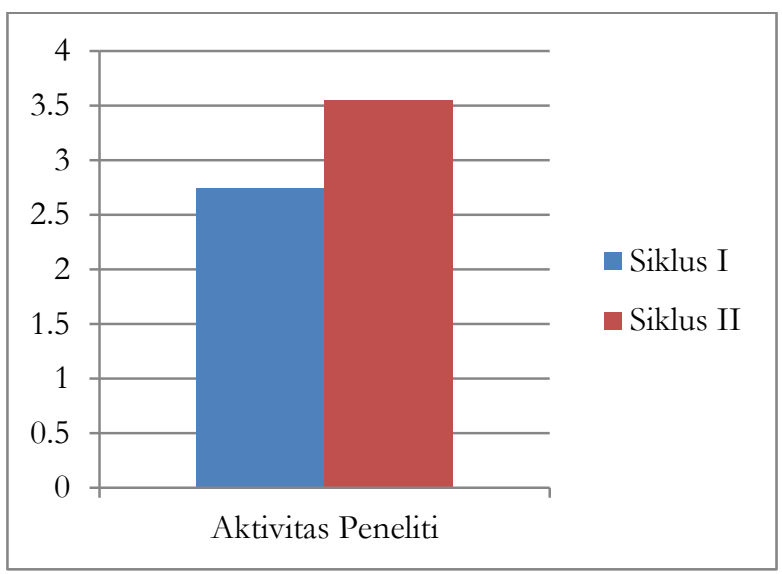

Gambar 4. Hasil Observasi Aktivitas Peneliti Pada Siklus I dan Siklus II.

Pada siklus I peneliti dalam menerapkan FGD masih terdapat beberapa hal yang perlu diperbaiki, sedangkan pada siklus II peneliti telah melakukan perbaikan pelaksanaan FGD berdasarkan hasil refleksi pada siklus I. Berdasarkan hasil pengamatan peningkatan aktivitas dan kinerja peneliti dengan indikator pengamatan: 1) pengelolaan dalam pelaksanaan FGD. 2) manajemen waktu, dan 3) penguasaan konsep pembimbingan dan motivasi, dan 4) penguasaan materi pengunaan TIK untuk pembelajaran daring didapatkan data bahwa rata-rata kemampuan peneliti melakukan FGD untuk meningkatkan motivasi dan keterampilan guru menggunakan TIK, mendapatkan rata-rata nilai sebesar 2,74 dengan kategori baik (B-) pada siklus I dan meningkat 0,81 poin menjadi 3,55 dengan kategori (A) pada siklus II.

4. Peningkatan Keaktifan Guru (Subjek Penelitian)

Dalam pelaksanaan FGD pada setiap siklusnya juga mengindikasikan keaktifan guru selaku subjek penelitian semakin meningkat. Data peningkatan keaktifan guru dapat dilihat pada tabel 4 dan gambar 5. 
Tabel 4. Hasil Observasi Keaktifan Guru (Subjek Penelitian)

\begin{tabular}{llcccc}
\hline \multirow{2}{*}{ No } & \multirow{2}{*}{ Indikator Keaktifan } & \multicolumn{2}{c}{ Siklus I } & \multicolumn{2}{c}{ Siklus II } \\
& & Banyak Guru & Persentase & Banyak Guru & Persentase \\
\hline 1. & Perhatian guru & 49 & $100 \%$ & 49 & $100 \%$ \\
2. & Keseriusan guru & 248 & $55,56 \%$ & 49 & $100 \%$ \\
3. & Keberanian mengemukakan & 16 & $33,33 \%$ & 35 & $77,55 \%$ \\
& gagasan (problem dan solution) & & & & $92,50 \%$ \\
\hline
\end{tabular}

Jika disajikan dalam bentuk diagram akan tampak seperti pada gambar 5 sebagai berikut.

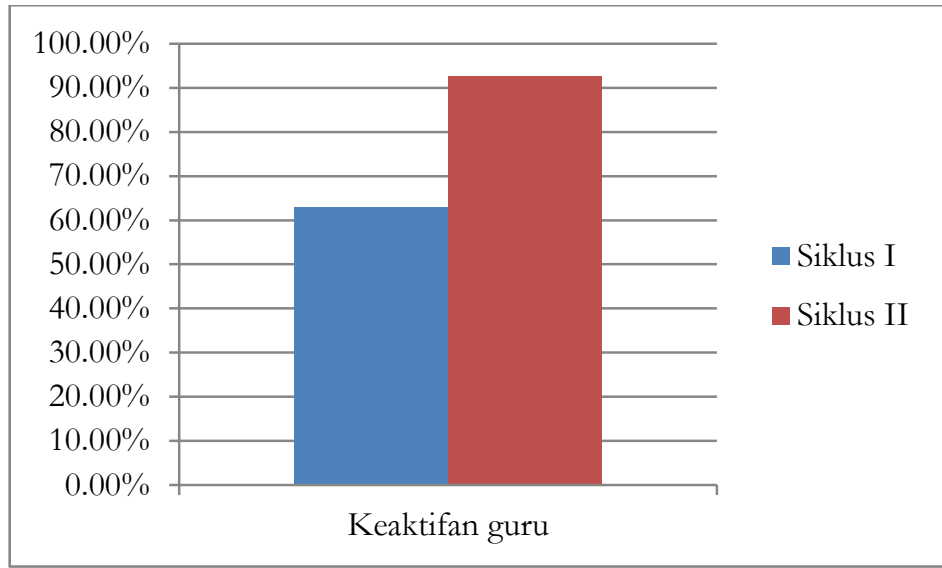

Gambar 5. Hasil Observasi Keaktifan Guru (Subjek Penelitian)

Dari tabel 4 dan gambar 5, tampak pada siklus I rata-rata keaktifan guru mencapai 62,96\% dalam kategori aktif dan pada siklus II meningkat sebesar 29,63\% menjadi 92,59\% dengan kategori sangat aktif.

Dengan kegiatan FGD yang telah dilakukan oleh peneliti, ternyata berdampak positif terhadap peningkatan motivasi dan keterampilan guru menggunakan TIK bagi guru SMP Negeri I Gegesik Kabupaten Cirebon pada semester I tahun pelajaran 2020/2021 dalam pelaksanaan pembelajaran daring di masa pandemi covid-19. Sebagai salah satu program tindak lanjut kegiatan, peneliti selalu memantau proses kegiatan pembelajaran dengan cara melakukan supervisi akademik bagi guru SMP Negeri I Gegesik Kabupaten Cirebon

\section{Kesimpulan}

Berdasarkan hasil penelitian yang dilakukan, dapat disimpulkan FGD yang dilakukan dapat meningkatkan motivasi dan keterampilan menggunakan TIK bagi guru SMP Negeri I Gegesik Kabupaten Cirebon dalam pelaksanaan pembelajaran daring di masa pandemic covid 19 pada semester I tahun pelajaran 2020/2021. Pelaksanaan FGD juga meningkatkan profesionalisme peneliti juga sebagai kepala sekolah pada tempat penelitian. Hal ini dibuktikan dengan meningkatnya kemampuan peneliti dalam mengelola kegiatan FGD yang dilakukan. Di samping itu, selama pelaksanaan FGD, keaktifan guru meningkat dalam melaksanakan pembelajaran daring dimasa pandemic covid 19.

\section{Daftar Pustaka}

Anugrahana, A. (2020). Hambatan, Solusi dan Harapan: Pembelajaran Daring Selama Masa Pandemi Covid-19 Oleh Guru Sekolah Dasar. Scholaria: Jurnal Pendidikan Dan Kebudayaan, 10(3), 282-289. 
Astuti, A. (2019). Peran Kepala Sekolah Sebagai Supervisor Dalam Meningkatkan Mutu Pendidikan. Adaara: Jurnal Manajemen Pendidikan Islam, 5(1).

Hutagalung, J. (2018). Penerapan Supervisi Klinis Melalui Focus Group Discussion dalam Meningkatkan Kinerja Guru di Sekolah Binaan Kecamatan Medan Deli. PROVEDENSI: Jurnal Pendidikan dan Teologi, 1(2), 49-69.

Jasman, J. (2017). Kompetensi Sosial Kepala Madrasah Dan Guru Dalam Meningkatkan Mutu Pendidikan Islam. Belajea; Jurnal Pendidikan Islam, 2(2), 181-214.

Kasir, K. (2018). Peningkatan Kemampuan Kepala Sekolah Dalam Pelaksanaan Program Supervisi Melalui Focus Group Discussion (Fgd) Di Gugus Iii Kecamatan Tampan Kota Pekanbaru. Jurnal Pendidikan Guru, 1(2), 27-41.

Khairuddin, K. (2020). Kepemimpinan Kepala Sekolah di Tengah Pandemi COVID19. EDUKASI, 8(2), 171 - 183.

Maimunah, M., Komariah, N., \& Asnawiyah, A. (2019). Peran Kepala Sekolah Dalam Meningkatkan Kinerja Tenaga Kependidikan Di Mts Nurul Huda Parit 5 Sungai Luar Kecamatan Batang Tuaka Kabupaten Indragiri Hilir. Al-Afkar: Jurnal Keislaman \& Peradaban, 7(2), 21-38.

Marzuki, M., \& Irawati, I. (2018). Pelayanan Kepala Sekolah terhadap Tenaga Pendidik di Sekolah Dasar Negeri 01 Benteng Hulu Kecamatan Mempura Kabupaten Siak. Indonesian Journal of Islamic Educational Management, 1(2), 112-125.

Muflihah, A., \& Haqiqi, A. K. (2019). Peran Kepala Sekolah dalam Meningkatkan Manajemen Mutu Pendidikan di Madrasah Ibtidaiyah. Quality, 7(2), 48-63.

Muslih, M. (2020). "Superman" Meningkatkan Kemampuan Kepala Sekolah Dalam Menyusun Administrasi Sekolah Di Gugus 04 Kecamatan Babat Kabupaten Lamongan. Mudir: Jurnal Manajemen Pendidikan, 2(2), 71-90.

Nahdi, D. S., \& Jatisunda, M. G. (2020). Analisis literasi digital calon guru SD dalam pembelajaran berbasis virtual classroom di masa pandemi covid-19. Jurnal Cakrawala Pendas, 6(2).

Nuruningsih, S., \& Palupi, R. E. A. (2021). Peningkatan Kompetensi Guru Dalam Penyusunan Rencana Pelaksanaan Pembelajaran (RPP) dengan Metode Focus Group Discussion pada Kegiatan In House Training (IHT) bagi Guru di SDN Pondok 03. Jurnal Dimensi Pendidikan dan Pembelajaran, 9(1), 51-57.

Puspitasari, H. (2018). Standar proses pembelajaran sebagai sistem penjaminan mutu internal di sekolah. Muslim heritage, 2(2), 339-368.

Ridho, M. A. (2019). Kepemimpinan Kepala Sekolah Dalam Mengembangkan Budaya Sekolah Efektif Di Sekolah Dasar. JDMP (Jumal Dinamika Manajemen Pendidikan), 3(2), 114-129.

Siregar, S. (2018). Meningkatkan Kemampuan Guru Dalam Menerapkan Pembelajaran Kontekstual Melalui Focus Group Discussion (FGD) DI SMK Negeri 1 Sirandorung Tahun Pelajaran 2017/2018. NUS ANTARA: Jurnal Ilmu Pengetabuan Sosial, 5(1), 14-19.

Wahed, A. (2016). Model Kepemimpinan Kepala Madrasah dan Permasalahannya. Jurnal Al-Ibrah, 1(1). 